\title{
Başarısız Perianal Fistül Tedavisi Nedeni: Perianal Endometriozis
}

\section{Reasonof Failed Perianal Fistula Treatment: Perianal Endometriosis}

Mehmet Biçer ${ }^{1}$,

Murat Çakır ${ }^{1}$

${ }^{1}$ Necmettin Erbakan Üniversitesi Meram Tıp Fakültesi Genel Cerrahi AD, Konya, Türkiye

Geliş Tarihi/Received: 29 Eylül 2018

Kabul Tarihi/Accepted: 26 Ocak 2019

Yazışma Adresi: Mehmet Biçer, Necmettin Erbakan Üniversitesi, Meram Tıp Fakültesi, Genel Cerrahi Ana Bilim Dalı, Konya, Türkiye e-posta: mehmetbicer08@hotmail.com

ORCID

Mehmet Biçer

https://orcid.org/0000-0002-6143-1918 Murat Çakır

https://orcid.org/ 0000-0001-8789-8199

\begin{abstract}
Öz
Endometriozis; endometrial dokunun uterus dışında başka bölgeye yerleşmesidir. En sık periton, overler, douglas ve rektovajinal septumda yer almakla birlikte vücutta birçok bölgeye yerleşebilir. Olgumuz 26 yaşında mükerrer başarısız perianal abse ve fistül cerrahisi sonrası değerlendirildi. Hastada perianal bölgede ağrı, şişlik ve akıntı mevcuttu. Cerrahi esnasında perianal bölgesindeki sertlik mevcuttu. Sertlik total olarak eksize edildi. Histopatolojik incelemede endometriozis olarak değerlendirildi. Endometriozisin alışılagelmiş yerleşim lokalizasyonlarından farklı bölgelerde oluşabileceği akılda tutulmalıdır.

Anahtar Kelimeler: Endometriozis, Perianal, Abse, Fistül

\section{Abstract}

Endometriosis is theplacement of theendometrialtissue in anotherpart of the body. Most commonly involved in peritoneum, ovaries, douglas and rectovaginal septum. It can be placed in many parts of the body. Our case was evaluated at 26 years of age after failed perianal abscess and fistula surgery. The patient has pain, swelling and discharge in the perianal region. The stiffness in the perianal region was seen during surgery. The stiffness was totally excised. Histopathological examination revealed endometriosis It should be kept in mind that endometriosis may occur in different regions from the usual localization.
\end{abstract}

Keywords: Endometriosis, Perianal, Abscess, Fistula

\section{GíRiş}

Endometriozis; endometrial dokunun uterus dışında vücudun başka bir bölgesine yerleşmesidir (1). En sık periton, overler, douglas ve rektovajinal septumda yer almakla birlikte vücutta birçok bölgeye yerleşebilir. Pelvis haricinde vücudun başka bölgelerine yerleşen endometriozis odaklarına ekstrapelvik endometriozis denir. Ekstra pelvik endometriozis görüldüğü yerler ve görülme sıklığına göre; incebarsaklar, umblikus, abdominal kesi skarları, farklı cilt bölgeleri, plevra, pankreas, akciğerlerdir. olarak sıralanabilir(2).

Endometriozis yerleştiği bölgeye göre farklı klinik prezentasyonlara neden olabilir. Yerleşim yerine göre hematemez, hematokezya, peritoneal iritasyon bulguları, hematüri, abse ile karışan kanamalı cilt lezyonları gibi farklı klinik tabloyla gelebilir. Ancak bütün bu bulguların hepsinde semptomların menstrüel siklusa eşlik etmesi ortak noktadır $(1,3,4)$.

$\mathrm{Bu}$ olgu sunumunda; menstrüel siklusla ilişkili perianal bölgede ağrı, kızarıklık, şişlik ve akıntı yakınmaları olan patoloji sonucu ile endometriozis tanısı alan fistül vakamızı literatür verileri ışı̆̆ında sunmayı amaçladık.

\section{OLGU}

Yirmi altı yaşında bir kez normal doğum yapmış bir kadın hasta nüks perianal abse, fistül nedeniyle değerlendirildi. Hasta dört yıl önce normal doğum yapmış. Doğumdan 1 yıl sonra şikâyetleri başlamış. Doğum esnasında müdahale ve epizyotomi 


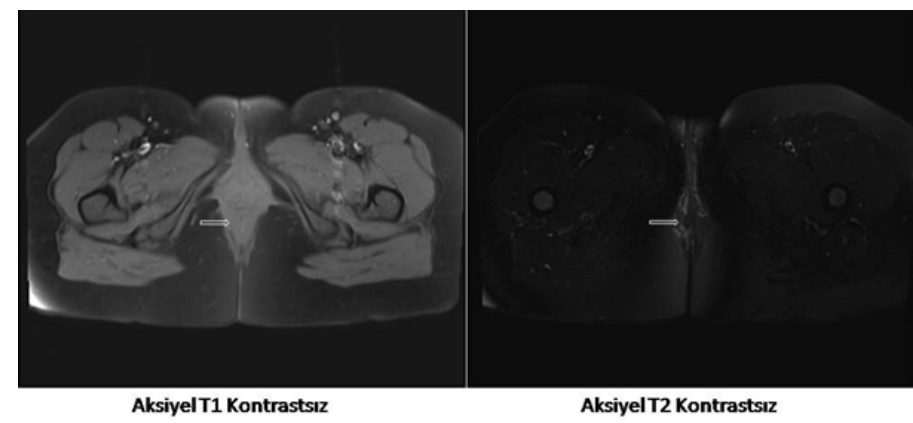

Şekil 1. MR fistülografi görüntüsü

yapılmamış. Özellikle her ay olan menstrüasyonla aynı zamanda gerçekleşen perianal bölgede ağrı, kızarıklık, ele gelen şişlik şikâyeti ile çeşitli dış kurumlarda mükerrer cerrahi ve medikal tedavi uygulanmış. Hastaya uygulanan cerrahi işlem sayısı 10'dan fazla olmuş. Kliniğimizde hasta değerlendirildi. Diz-dirsek pozisyonunda yapılan muayenede saat 3-4 hizasında sert kıvamlı, palpasyonla hassasiyeti ve ortasında fistül ağzı olan lezyon görüldü. Mükerrer cerrahilere bağlı skarlar izlendi. Nüks perianal fistül olduğu için görüntüleme tetkiklerine başvuruldu. Yapılan Magnetik Rezonans (MR) fistülografik incelemede anal kanal sağ posterolateralinde cilt altı yağlı dokuya uzanan $21^{*} 12 \mathrm{~mm}$ boyutlarında perinal abse ve kör sonlanan fistül traktı görüldüğü ifade edildi (Şekil 1). Preoperatif hazırlık sonrası ameliyata alındı. Litotomi pozisyonunda saat 9-10 hizasında fibrozis veya tümöral yapıyı maligniteyi de düşündürebilecek alan izlendi. Kitle sfinkter hasarı oluşturulmadan total olarak çıkarıldı. Kitlenin rektum veya anal kanalla

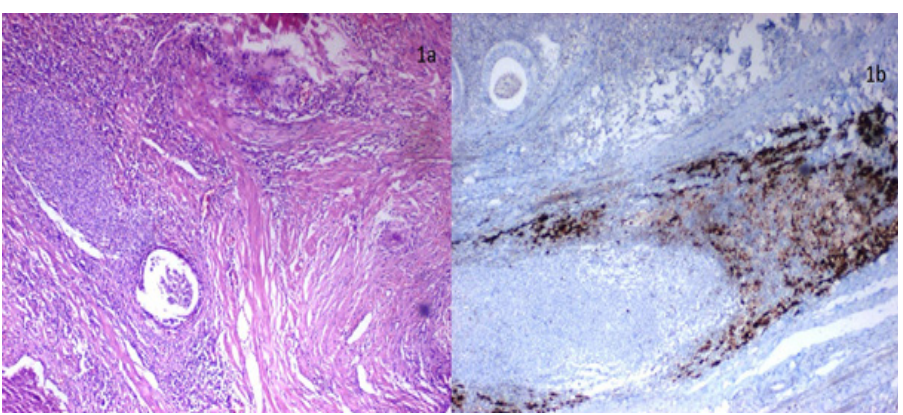

Şekil 2. Histopatolojik incelemesi (1a: x 40 H\&E fibroadipöz dokular içinde endometrial stromal ve endometrial glandüler yapılar, 1b: x40 CD-10 immünhistokimyasal cd 10 hücrelerde pozitif )

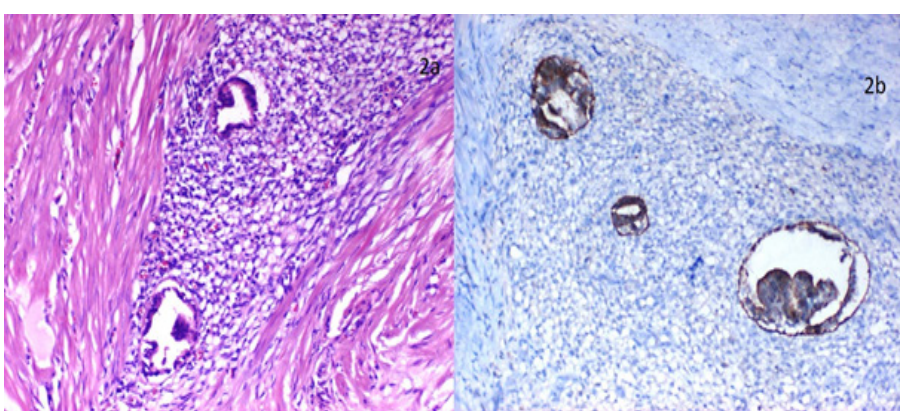

Şekil 3. Gland yapıları ve içerisindeki kanama alanları (2a: x100 H\&E, 2b: x100 Pan-CK pansitokeratin endometrial glandüler yapılarda pozitif)

bağlantısı olmadığı tespit edildi. Lezyonun bütünlüğü korundu.

Eksize edilen dokunun makroskopik incelemesinde içerisinde nekrotik mayiye benzeyen kokusuz, hemorojik komponenti de olan yapılar izlendi. Histopatolojik olarak vimentin ve pansitokeratin koekspresyonu gösteren glandüler yapıların görülmesi nedeniyle endometriozis eksterna olarak değerlendirildi (Şekil 2, 3). Hastanın 10 aylık takibinde nüks izlenmedi.

\section{TARTIŞMA}

Endometriozis doğurganlık çağında bulunan kadınların \%2-22 oranlarında bulunur (5). Endometriozis tanısında MR görüntülemede daha değerlidir. Çünkü lezyon içindeki kanama odaklarını MR daha iyi göstermektedir (6). Endometirozisin pelvise ya da vücudun başka bölgelerine yerleşmesi ile ilgili çeşitli teoriler vardır. Endometriozisin pelviste oluşumu menstrasyon sonrasında geriye doğru endometrial dokunun peritona dökülmesi ile açıklanmaktadır. Diğer vücut bölgelerine endometrial dokunun nasıl taşındığı hayvan deneyleri ile yapılan bir çalışmada gösterilmiştir (7). Bu çalışmada mens sırasında endometrial dokunun periton ya da cilt altına ekilerek pelvis dışına endometriozis yapılabileceği gösterilmiştir. Olgumuzda doğum sonrası ekim olduğunu düşünmekteyiz. Ancak doğumdan 1 yıl sonra nasıl doğum sonrası 1 yıl sonra ortaya çıktığını izah edemedik. Belki de kanımızca belirtilerin ortaya çıkması için belirti vermek için adet döneminin başlaması ve lezyonun belli boyuta ulaşması gerekmekteydi. Travma olmamasına rağmen endometrial doku perianal bölgeye implante olmuştur. 
Endometriozisin tedavisi cerrahi eksizyondur. Cerrahi eksizyonun mümkün olmadığında medikal menapoz yapan ilaçların (gonadotropin salgılatıcı hormon analogları, danazol) kullanılması da bir diğer seçenektir (8). Sezeryen sonrası cilt skarında endometriozis literatürde görülse de insizyondan uzak, bağımsız bir bölgede endometriozis görülmesi nadir bir durumdur. Bu nedenle olgumuz ender görülen bir endometriozis olgusudur. Tedavide lezyona total eksizyon uygulandı. Hastanın yaklaşık 10 aylık takibinde nüks ve o bölgede sertlik oluşmadı.

Geçmeyen perianal abse ve nüks fistüllerde patoloji örneklemesi yapılması ayırıcı tanıda önemlidir. Normal doğum esnasında endometrial doku kalıntılarının uzaklaştırılması gerekir. Endometrial dokunun bulaşabileceği yerler serum fizyolojik ile irrige edilmesinin endometriozisin oluşmasına engel olabileceği düşünülmektedir. Olgumuz sık nüks eden ve perianal abse nedeniyle drenaj yapılmış olguydu. Kadın hastalarda başarısızlıkla sonuçlanan perianal fistül tedavilerinde olgunun endometriozis olabileceği akılda tutulmalıdır.

Çıkar Çatışması: Çalışmada herhangi bir çıkar çatışması yoktur.

Finansal Çıkar Çatışması: Çalışmada herhangi bir finansal çıkar çatışması yoktur.
Yazışma Adresi: Mehmet Biçer, Necmettin Erbakan Üniversitesi, Meram Tıp Fakültesi, Genel Cerrahi Ana Bilim Dalı, Konya, Türkiye

Telefon: 903322236123 E-mail:mehmetbicer08@hotmail.com

\section{KAYNAKLAR}

1. Machairiotis N, Stylianaki A, Dryllis G, et al. Extra pelvic endometriosis: A rare entityor an underdiagnosed condition? Diagn Pathol 2013;8:194.

2. Dutta $P$, Bhat $M H$, Bhansali $A$, et al $A$ young woman with endometriosis of kidney. Saudi Med J. 2006;27(2):244-6.

3. Vercellini P, Vigano P, Somigliana E, et al. Endometriosis: Pathogenesis and treatment. Nat Rev Endocrinol 2013;10:261-75.

4. Aktan E, Kaleli B, Demirkan N, et al. Rektosigmoid muskuler tabaka ve ekstrensek yüzeyel üreteral tutulum gözlenen bir endometriosis olgusu. Türk Fertilite Dergisi 1997;3:220-4.

5. Al-Khawaja M, Tan PH, MacLennan GT, et al. Ureteral endometriosis: Clinicopathological and immunohistochemical study of 7 cases. Hum Pathol 2008;39(6):954-9.

6. Pérez-Utrilla M, Aguilera Bazán A, Alonso Dorrego JM, et al. Urinary tract endometriosis: Clinical diagnostic and therapeutic aspects. Urology 2009;73(1):47-51.

7. D'Hooghe TM, Bambra CS, Isahaki M, et al. Intrapelvic injection of menstrual endometrium causes endometriosis in baboons. Am J Obstet Gynecol 1995;173:125-34.

8. Purvis RS, Tyring SK. Cutaneous and subcutaneous endometriosis. Surgical and hormonal therapy. J Dermatol Surg Oncol 1994;20:693-5. 